\title{
Hearing Voices: From the Experience Qualification to the Possibility of Care
}

\author{
Henrique Campagnollo Dávila Fernandes ${ }^{1, *}$ (1) \& Valeska Zanello (b \\ ${ }^{1}$ Centro Universitário do Planalto Central Apparecido dos Santos (UniCePlac), Gama, DF, Brasil \\ ${ }^{2}$ Universidade de Brasília, Brasília, DF, Brasil
}

\begin{abstract}
This article aimed to analyze hearing voices experiences in patients of a Psychosocial Care Center. In this regard, ten people were interviewed. The qualitative method was used, with content analysis. Four categories were chosen: "origin" of voices, phenomenology of voices, coping strategies, and family support. Hallucinatory experiences have emerged in contexts of violence and isolation. Topographic variables of the voices indicate possibilities of understanding the phenomenon. The movement is a basic condition to deal with the experiences. Family support is key to cope with difficulties. It is necessary to qualify the auditory hallucination as a meaningful experience, which must be respected in any intervention that intends care.
\end{abstract}

KEYWORDS: auditory hallucination, mental health, Psychosocial Care Center

\section{Escutar (as) vozes: da Qualificação da Experiência à Possibilidade de Cuidado}

\begin{abstract}
RESUMO - Este artigo teve como objetivo analisar experiências de audição de vozes de pacientes de um Centro de Atenção Psicossocial. Para isso, foram entrevistadas dez pessoas. Foi utilizado o método qualitativo, com análise de conteúdo. Foram eleitas quatro categorias: "origem" das vozes, fenomenologia das vozes, estratégias de lida, e suporte familiar. Observou-se que as vivências alucinatórias surgiram em meio a contextos de violência e isolamento. Variáveis topográficas que constituem as vozes indicam possibilidades de compreender o fenômeno. Movimentar-se apresentou-se como condição básica para a lida com as experiências. O suporte familiar mostrou-se essencial para o enfrentamento das dificuldades. Conclui-se que é necessária uma qualificação da alucinação auditiva como experiência plena de sentido, a qual deve ser respeitada em qualquer intervenção que se proponha ao cuidado.
\end{abstract}

PALAVRAS-CHAVE: alucinação auditiva, saúde mental, CAPS

"Doctor, do you know that I have heard many voices? Do you know what I did? I bought a helmet to sleep. I realized that when I rode a motorcycle, they left me alone. And I was having trouble sleeping". Thus began the speech of one of the members of a psychotherapeutic group of a Psychosocial Care Center (CAPS) ${ }^{1}$, intended for the care

1 CAPS is designed to embrace and treat people in severe psychological distress, and/or who are addicted to alcohol and other drugs through support from a multiprofessional health team. of people in severe psychological distress ${ }^{2}$. He continued: "Then I put one on when they were making me crazy, and I misled them. I asked my mom to buy five. Because with the helmet, we sweat a lot, all night, so it's one for each day of the week, and it doesn't smell bad".

2 Relating to forms of manifestation of anguish, which are not well understood or accepted by the culture/social environment. The term "severe" refers to the demand for specialized care for treatment (Costa, 2013).

\footnotetext{
*E-mail: hcdfernandes@gmail.com

- Submetido: 11/08/2017; Aceito: 17/10/2018.
} 
The above speech presents us with a strategy adopted by a voice hearer to not be so bothered by the voices. However, most people who undergo treatment at the center surveyed show that they cannot find ways to cope with the issue and report great suffering. This is because hallucination is a disturbing experience, so much so that the voice-hearer cannot work or study and even attempt suicide (Kalhovde et al., 2013). Commonly hearing voices cause isolation and difficulty establishing important support networks for mental health and the recovery process ${ }^{3}$ (Baker, 2009).

Such a phenomenon has been documented since antiquity (Longden et al., 2012). In the seventeenth century it started to be studied within the scientific/biomedical model, and at the end of the eighteenth century by neurology and psychiatry (Telles-Correia, Moreira, \& Gonçalves, 2015). This scenario began to change in 1987, in Europe, with the efforts of Marius Romme and Sandra Escher, who began research comparing clinical (under psychiatric treatment) and nonclinical voice hearers, and understanding the phenomenon no longer as a sign of mental illness (Hill \& Linden, 2013).

With the support of voice hearers, Romme and Escher founded the Hearing Voices Movement $(\mathrm{HVM})^{4}$ (Corstens et al., 2014), which is present in European, Asian, North American and Oceania countries. HVM offers support networks alternative to the biomedical logic, with good results - such as medication reduction and increased wellbeing (Corstens et al., 2014) - and provided the basis for voice hearing to be researched in a number of ways: to know how voice hearers evaluated peer dialogues; combining psychoeducation with exchange of experiences; surveying effects of groups of voice hearers, among others (Romme, 2009a).

In Brazil this reality is different. Hallucinatory experiences are most often reported in spaces intended for mental health treatment or in religious groups that value and

3 It concerns recovery, a process that goes beyond the conception of cure or remission of symptoms and is achieved when the user rescues hope, improves his/her quality of life and regains aspects of the existence that he/she lost due to illness. It becomes possible through the joint action of external factors (such as the care provided by mental health services) and internal factors (own resources) (Baccari et al., 2015). Such a concept will be seen quite often in this article.

4 HVM is currently coordinated by Intervoice - International Network for Voice Hearing Training, Education and Research (Longden et al., 2013, p. 162, our translation). foster anomalous experiences (AEs) ${ }^{5}$ - such as charismatic Catholics, Pentecostal Protestants, Afro-Brazilian religions, and spiritists (Alminhana \& Menezes, 2016). In the field of mental health, auditory hallucination is understood according to psychiatry manuals ${ }^{6}$ and treatment follows the traditional methodology - prescription of drugs aimed at remission of symptoms.

As for the religious groups mentioned, they are sought by the voice hearers to give meaning to their experiences and to remove the stigma of madness, because beliefs consider AEs as manifestations of the divine (Godoy, 2012) and/or sign of mediumship (Almeida, 2004). However, there are cases in which religious leaders direct the person to seek professional help, usually when hallucinatory experiences involve elements such as: social and occupational harm; suffering and comorbidities; frequent and long-lasting occurrences; and lack of experience control (Menezes \& Almeida, 2009).

Similar criteria are used to distinguish clinical from non-clinical voice hearers (Daalman et al., 2011; Badcock \& Chhabra, 2013; Baumeister et al., 2016). They are critical in preventing an $\mathrm{AE}$ from being confused with a mental disorder symptom and resulting in iatrogenic problems and misdiagnosis (Almeida \& Cardeña, 2011). Whether it is a clinical case or not, trying to understand how experiences are structured in people's lives is fundamental for care (Baker, 2009) and helps in the development of appropriate intervention strategies for each case (McCarthy-Jones et al., 2014). In the field of mental health, these measures are essential, since many voice hearers have been undergoing medication treatment for years and report great suffering due to hallucinations and side effects of the drugs, without any resolution to this issue.

Considering these points, this study aimed to analyze voice hearing experiences of people treated in the public health system, in order to contribute to reflections on new ways of understanding and caring for this phenomenon. For this, patients of a Psychosocial Care Center were interviewed and their reports were analyzed according to the procedures described below.

5 They refer to unusual experiences, or those that, although commonly reported, are understood to be different from the usual, and not belonging to reality (Almeida \& Lotufo Neto, 2003).

6 Diagnostic and Statistical Manual of Mental Disorders (DSM-5) and Classification of Mental and Behavioral Disorders of the International Classification of Diseases (CID-11). 


\section{METHOD}

This study was part of an empirical research aiming to problematize the traditional logic of the management of auditory hallucination. The qualitative methodology was used, as it sought to explore and understand meanings associated with hearing voices through reports of people who live with this type of experience. The selected site was a Psychosocial Care Center (CAPS) for the care of people in severe psychological distress in a Brazilian capital. To start the research, the project was presented and agreed with the CAPS technical team, and followed the necessary procedures for authorization by the ethics committees of the responsible bodies - the Higher Education Institution and the Health Secretariat - and was approved with CAAE 52032315.6.0000.5540 and 52032315.6.3001.5553.

The participants attended at least once a group of voice hearers, which had one of the researchers as a facilitator, and four were no longer being treated at CAPS. In all, fifteen voice hearers were invited to participate and received information about the research. Ten accepted the invitation, four men and six women, with the following profile: ages between 25 and 54 years old; diverse race, treatment time, heterogeneous economic condition and diagnoses; varied religion and/or religious practices ${ }^{7}$ - four believed in spiritualism, three were evangelical, one was catholic, and two made no reference to any belief; and time hearing voices between 2 and 46 years.

The interviews were scheduled according to people's availability. Some of them were interviewed at CAPS, and others preferred to have it done at their place of residence. Eight were recorded on audio, while two participants chose not to record because they had already delusions with sound transmission devices, and were not comfortable with this type of instrument. In these cases, the reports were written by the researcher on separate sheets, while the interviewees

7 In this study, the terms religion, religiosity and spirituality, appear quite often. According to Koenig et al. (2012), religion is an organized system of rituals, beliefs, practices, and symbols designed to bring the person closer to the sacred and to provide an understanding of community life. Religiosity is an involvement or commitment to a religion (Hardy \& Carlo, 2005). Spirituality is a personal search for responses that lead to an understanding of the meaning of life and to the relationship with the sacred, which can take place through religious rituals (Koenig et al., 2012). spoke, which made these two interviews last 1 hour and 15 minutes, and 30 minutes. Subsequently, each interviewee was read what had been written through their testimony to check for something to rectify. Together, the interviews totaled 8 hours and 30 minutes, with an average time of 51 minutes.

For data collection, a semi-structured interview script was used, elaborated from: (a) the instrument Voice hearing: a questionnaire (Escher et al., 2011); (b) questions that Romme et al. (2009) listed as fundamental for understanding the relationship between the person and their voices and for establishing therapeutic paths ${ }^{8}$; (c) experiences with the voice hearers group at CAPS. Thus, themes such as coping strategies, characteristics of voices, events related to the emergence of voices and family support were explored through eight questions": (1) "Tell me about your life story"; (2) "Do you remember when you started hearing voices?"; (3) "How was the first experience?"; (4) "Has anything happened that you can associate with the rise of voices?"; (5) "What do you do when the voices start talking?"; (6) "How do you understand hearing voices?"; (7) "What do they say?"; 8) "What is the family's attitude towards this".

Data were analyzed according to content analysis techniques (Bardin, 2016). The analytical method was performed in four moments: (1) free reading of the transcribed material (audios and written interviews); (2) reading with survey of themes in each interview; (3) comparison of themes between interviews and construction of categories (for all interviews); (4) grouping excerpts of each interview into the categories. The four categories listed were: "origin" of voices, phenomenology of voices, coping strategies, and family support. Each will be explained and illustrated with excerpts of the interviewees' reports in the next topic. Fictitious names were used in the excerpts and personal data were omitted in order to ensure confidentiality.

8 These authors are part of Intervoice and came to these questions through reports of voice hearers, after years of research, support, work and coexistence with them.

9 We emphasize that when the person has the impression that the voices come from another entity, one should ask "who are these voices?", a question that opens the possibility for the integration of meaning and deals with the manifestations - as observed in reports from some respondents. 


\section{RESULTS AND DISCUSSION}

\section{“Origin" of Voices}

This category groups and analyze data related to the emergence of voices, such as striking events, life contexts and meanings that the research subjects gave to the occurrence of the phenomenon. From the respondents' answers, the "origin" of the voices was divided into two subcategories: (a) emergence context (themes that involved the first hearing experience in the interviewee's life); (b) etiological attribution (questions that the participants attributed to the emergence of voices - both in the biographical trajectory, and nowadays).

\section{Emergence Context}

The themes related to this subcategory were: domestic and psychological (extra-domestic) violence; isolation and loneliness; and the period of adolescence. Eight voice hearers reported experiencing domestic violence and/or living in environments where such violence was common. And four went through situations of psychological violence (prejudice in relation to mental health condition) and/or bullying, like Reinaldo: "I started running away because I was embarrassed, everyone called me a fagot, and I was ashamed to go outside."

Reinaldo did not complete elementary school, and his cycle of psychiatric hospitalizations began in adolescence. His case and many other patients at CAPS attest that violence can lead to serious health conditions and interfere with lifelong development (World Health Organization, 2014). That is, violence can leave marks that may be at the root of hearing voices, especially negative voices, when the episode of violence is not shared (Romme, 2009b), which is shown to be very present in the life of clinical voice-hearers. (Honig et al., 1998; Kråkvik et al., 2015).

Contexts of loneliness and isolation were part of the ten interviewees at some point in their lives, and occurred as a result of situations of violence; when family members, friends or acquaintances of daily life had left when they knew that the interviewees heard voices; as a result of the hospitalization process and treatment in the mental hospital or CAPS. As a result, they found it difficult to build support networks to cope with their suffering and their hallucinatory experiences got worse.

Adolescence was a period often cited - nine respondents mentioned it as the most troubled, with many conflicts. According to Marcela:

In my teens, my parents were alcoholics, I had a lot of nervous tension, a lot of fear (...) when the family is alcoholic, there are fights, quarrels, and because my family is so unstable, I always saw that, I suffered a lot. I was a morbid obese in my teens, suffered a lot of discrimination, so I think it all came together, and I had a hard time relating to people (...) I felt very complex, so I think it was all helping the voices.

Fábio significantly portrayed the relationship of this period with his illness: "adolescence is a difficult time; the bombs are implanted, and as adults the psychiatric problems appear". Intensely painful situations in adolescence reflect in subsequent periods of life, and the lack of a support network or mechanisms (such as school, family, and policies) to address adolescents with problems such as these can become a risk factor for mental health (World Health Organization, 2014) - as was the case with some of the interviewees. Only one of them was embraced by the family when reporting his/her emotional difficulties. The others were considered "crazy" and some were taken to the mental hospital or psychiatrist.

\section{Etiological Attribution}

It grouped the following themes: sexual violence, religious or spiritual experiences and "triggers" (events that make the person feel pressured and/or generate tension, feelings and emotions, and that result in the manifestation of voices). Four respondents (three women and one man) reported having suffered some kind of sexual violence and reported suffering and problems of various kinds as a result, such as Larissa:

I was eleven, when I was abused. So, things went awry, so (...) at fourteen I began to feel sadness, to be isolated, friends moved away. I started to feel scared, lost sleep. As soon as I had my daughter, I had postpartum depression, my grandmother died days later. I was very sad, I started to see figures. Then came the voices, sometimes it was command voices, they wanted me to do something bad. Then my mother took me to Hospital " $X$ ". I stayed there a while, came the urges to kill myself, I tried several times, I was hospitalized. Hospitalizations have always been difficult because they beat, hurt, tied, left without food.

According to the interviewee, her isolation process began with the rape - violence she related to the emergence of voices. She had the place of secrecy. There was also negligence on the part of a close person with whom she shared the fact, who refrained from helping her out of fear that some family member would kill the rapist (also part of the family). This decision gave a feeling of guilt to the interviewee, which manifested as a trigger in the process of hearing voices. In addition to the issues present in the excerpt, Larissa also suffered domestic violence from her exhusband - who threatened to separate from her in her crisis, in addition to committing other psychological violence. 
The three interviewees represent a worldwide reality: one in three women have suffered or will suffer sexual violence from a man other than their partner (World Health Organization, 2013); regarding the period of childhood, this goes from one to five women (World Health Organization, 2014). In a recent research, Pedrosa and Zanello (2016) pointed to a strong correlation between violence against women, the demand for mental health services, and mental disorders.

And with regard to auditory hallucinations, research points to the existence of a high interdependence between the phenomenon and sexual abuse (Shevlin et al., 2007; Longden et al., 2012). This data was corroborated by Campos and Zanello (2016), who found that $30.8 \%$ women undergoing treatment at a CAPS had suffered gender violence. In this group, women who experienced sexual violence had more reports of psychotic symptoms (such as auditory hallucination) than those who experienced other violence, such as physical and psychological. Read, Agar, Argyle, and Aderhold (2003) stressed that childhood sexual violence is a predictor of voice hearing.

Another issue in this subcategory referred to religious beliefs or spirituality, as Marta reported:

I went to the church, and the pastor revealed, I believe because I have never seen the pastor and he said a lot of a friend, " friend of yours is this way, but it is not her, it is the spirit that is in her, is jealous of you", that in her house they made an offering, and I ate, and then everything comes, and it was God taking it from me, which was on the spiritual surface, then I started to spit, but no food came out, just spit like water. That's $i t$, in the spirit world, the voices.

Four other respondents also associated the voices with this kind of experience, and reported that they came from spirits talking to each other and wanting to do evil, or that they were a mission from God, or a mediumistic gift. In Marta's case, the hearing of voices would have been caused by a demonic spirit, according to the host pastor. This explanation made a lot of sense to the interviewee, as the pastor established a coherent (for her) relationship between the voices and a life event. It also caused relief by allowing the partial "expulsion" of the entity in a disobsession ritual. With this, she made a religious commitment and sought to strengthen herself through prayer and attendance at the activities offered in this place.

Knowing the "origin" of voices therefore involves elements that belong to the repertoire of experiences and to the "worlds" of each person. In addition to religious or spiritual experiences, we have other elements such as popular culture - an important resource of creation and care in the clinic, which challenges traditional assumptions by assisting the recovery process (Costa \& Braga, 2013).
Regarding the triggers, we highlight an excerpt of Marta's speech:

So, at work, when I started I had the residue of depression, but I said "guys I need to help my mom", she was paying my bills, and there is a very strong psychological pressure, there is the director, the two owners, and that's all of glass, and everything that happens where we are, they keep looking, and fire the person just like "I don't like you, bye". There are cameras, and I was kind of stuck in that psychological pressure (...) Then comes the voices, what the director is thinking, "what is he thinking?"

In addition, eight respondents made clear the association between environmental and/or situational conditions, emotional state, mental pressure, and the "invasion" or worsening of voices. Memories of striking events and certain thoughts can also be triggers, just as stress and anxiety are considered determining factors in triggering voices (Barnes et al., 2011). Micaela talked about another important trigger:

It pulls into the hole, it opens and you sink, it is fear of death, it involves only bad things (...) fear generates expectation, I cannot sleep, it is as if that person could boss and have all the cards up its sleeve about me.

This excerpt highlights the value of emotions and feelings for the occurrence of voices, which besides being triggers (Longden et al., 2012) contribute to their permanence (Freeman \& Garety, 2003). Fear, loneliness, sadness and guilt were the emotions and feelings most associated with voices by respondents.

\section{Phenomenology of Voices}

This category refers to topographic variables of voices, such as intensity, frequency, number, content, identity, gender, how they present themselves, emotional valence, and level of influence, and appeared in the reports of the ten respondents. About the intensity and impact they cause. Marta stated that: "these are bad things for you to feel and hurt you, the pressure increases, the pulse". And Artur reported:

The disturbed in this situation try to pay attention to how hel she feels the heart, which begins to have certain sensations (...) and a detail, you have no control over the internal organs, it is as if the viscera were not yours, loses strength, gets shaky, it's like losing control over the body.

Amanda's report also happened in this direction: "it takes care of the environment; it is as if it echoes (...) depending on the state I am in they will affect me much more". In these excerpts, we could see that the voices intensify or alter the 
states or triggers that generated them. All other respondents talked about the high intensity of voices, with the loss of body control, which can result in dissociative states.

The variables frequency and number were different for each interviewee, and may be related to life history and triggers. As for content, Fabio reported: "They invade my privacy, my life, the intensity is sometimes constant, sometimes not. They say a lot of bad things that will happen to me; aggressive content that humiliates, makes you feel bad". And Reinaldo:

I have never had a healthy, normal active sex life, and when I imagine I will have, voices always come "Do you want to be gay? Being gay is the most ridiculous thing in the world", so Ifeel castrated because I never had a satisfying sex life, much suffering, caused me this schizophrenia disorder. And then I left voices saying that I cannot do what gives me pleasure or anything, unfortunately I have these desires, I did not want to have, but I am homosexual, yet I feel frustrated, and this situation is what makes me suffer the most.

The voices affect issues that structure people's lives, as observed in the reports presented, which leads us to think about the importance of valuing their content in therapeutic work for their understanding. This variable may have a connection to the "origin" of voices or suffering events, as Daniel reported:

They change tactics constantly, not only playing with your psychological part but with your body as well, they say things you don't like (...) I feel something in my butt, it bothers me, I have the feeling that I want to be touched, but I don't want, understand? I don't know if it has anything to do with that neighbor's experience.

Daniel referred to the sexual abuse he suffered from a much older friend as a child, a fact he did not share with anyone. The voices make him feel sensations in the parts that the aggressor touched, and problematize his sexual orientation - an issue that makes him very disturbed, to the point of seeking psychiatric help, because he feels the crisis is approaching. According to Beavan and Read (2010), content is the variable that most affects voice hearers and has a significant relationship with emotional responses; in addition, there is a greater demand for mental health services by people who hear voices that generate negative emotions - as it applies to the ten respondents. Only three of them heard "positive" voices, but infrequently.

As well as the variable content, it is possible that the identity of the voices may be related to people who marked the biographical trajectory of the voice hearer. Three interviewees made this association, like Reinaldo: "The one that bothers me most is the Jesse's voice, he hurt me a lot, to this day I try to forget him, but every time I try he comes to disturb me, he calls me a bastard, crazy". Two other research subjects said the voices were from known people.
Identity is a variable that can be sought in clinical work, as it can assist in the elaboration of conflicts that are at the root of manifestations (Escher, 2009a).

As for gender, only three respondents could not identify it (because the voices were mixed or sounded like a crowd). Such result problematizes findings of Badcock and Chhabra (2013), whose review pointed out that the gender of voices in clinical voice hearers had male predominance, while in non-clinical, this predominance did not occur. Among the respondents who were able to identify the gender, five reported that the voices were from known people, and spoke content related to life events, such as Amanda (who suffered sexual abuse from her father several times, from eight to twelve years old):

Most of the time it's negative man voice, always say things no one would say, "take medicine and get it over with", things like that. There is also the female voice, which is where the male is very intense, she tries to cross, when I'm very calm I can hear her, more serenity, gives advice, "everything is a phase, will pass", "don't listen to negative things", it comes like a mother, to calm me down.

Amanda's report corroborates Escher (2009a), who stated that gender is a variable that may be related to the content and identity of voices. This excerpt presents another topographic variable: the "form" that presented itself in three ways: criticism or judgment, supportive and suggestion or command. All respondents reported hearing voices that criticized actions taken or aspects of life, such as Marcela: "Hearing voices is a repression, 'you see, you shouldn't have done that". Only two heard voices that provided emotional support. And what most affected the interviewees were voices that gave suggestions or commands, because they had the power to influence them to commit acts of self and hetero-aggression, as Mirela reported: "The first time I heard a voice telling me to kill myself. I climbed on the walkway, tried to jump, it was horrible (...) I didn't know what I was doing".

All respondents said they heard commanding voices throughout their biographical trajectories and at the time of the study, six people were still affected by them. Seven interviewees attempted suicide, and all had suicidal ideation at least for a period of their lives because of their (intensely negative) emotional valence and their strong influence. Another feature that respondents reported about command voices is that they said that if commands were not followed, they would have even more serious problems - which is why they felt compelled to obey them.

Although command voices are not directly related to suicide attempts, they can influence people with affective disorders, substance-dependent, and who have attempted suicide at other times (Harkavy-Friedman et al., 2003). In addition, feelings such as failure and imprisonment (being in a "dead end") are mediators between commanding voices and suicide attempts (Taylor et al., 2010), as in the case 
of Micaela: "it's the worst, that you can't face, because otherwise you can fall into the hole for good". These data point to the need for more careful support when the voice hearer (whether clinical or not) reports the presence of command voices.

The topographic variable level of influence - which refers to the performance of acts according to the manifestations - however, not only included the command voices, but also the other two forms (judgment and support) and is related to variables such as intensity, frequency, content, identity, and emotional valence, as in Artur's case: "They say I will not achieve anything in life, I will always be worthless". Because of the repetition of this content and the dimension it took in Artur's life, he reported that he abandoned many projects and that this had several negative consequences for his life. The ten respondents reported having suffered losses due to the strong influence of the voices.

Findings regarding this category show that, as well as the "origin" of voices, topographic variables should be valued in therapeutic management, as they favor the process of understanding the phenomenon and open the possibility of better coexistence with voices (Baker, 2009).

\section{Coping Strategies}

In this category, we tried to present techniques that the interviewees used to withstand the voices or to live with them. Having strategies and exercising them is a crucial point in the recovery process, as it reduces the power of influence and the impact of voices, bringing greater mental well-being (Escher, 2009b). The interview data led to the division of strategies into active and passive - similar to that of O'sullivan (1994). The active strategies involved taking any action that would change the state the voice hearer was in when he/she began to hear them. They were subdivided into: physical activities, distraction activities, active attention manipulation activities, and religious or spiritual practices. Passive strategies were characterized by non-action.

All respondents had tried at least once some active strategy. Among them, we highlight those related to religion or spirituality, which were reported as beneficial by seven respondents, such as Daniel:

I learned to deal with the voices, reading the Bible, studying the Bible helped me a lot (...) Spirituality also helped, the spiritual side was totally dying, malnourished, I had to go back to a spiritual routine, to draw close to Jehovah God then everything went well.

Like Daniel, the other respondents felt comfort and less anguish when they made prayers, and in some cases the voices stopped manifesting. Another aspect mentioned was the participation in religious services, when the interviewees had contact with people who embraced them and advised them in difficult times. The results corroborate Almeida et al. (2006), in which getting involved with spiritual and/or religious beliefs and practices brings greater psychological well-being, besides the feeling of belonging to a group and social support.

However, it is noteworthy that it is not every religious/ spiritual practice that brings beneficial elements, since, as we have seen, there is the possibility of intensifying the voices and aggravating the suffering. This has happened to Reinaldo, who to this day resents having participated in some activities (such as exorcism rituals and incorporations of bad spirits) and meeting certain religious leaders (who were prejudiced, according to him) - since some memories are triggers for the voices.

Six subjects reported the search for physical activities. Mirela reported:

When they tell me to do something, I myself say "I won't do it", and I always try to distract myself, I go for a walk, if I am at home, or at work I talk to someone, I go to the bakery, I do something, I move, because if I stand still and listen, then they will overwhelm me.

The most common physical activities were walking and exercises in community-owned spaces or gyms, as Larissa stated: "Now that I'm starting to get a little better by doing walking, gymnastics, and that's a protection that is doing me good'. Still in Mirela's report, it was possible to observe the use of distraction activity: looking for someone to talk to, a strategy that was also made by phone - a good support tool, considering that some devices give access to the internet and social networks. Some respondents even asked for help with text or audio messages in the virtual group created by members of the voice hearers group of CAPS and were helped to use strategies that got them out of impending crises.

The least-used active strategy was attention manipulation, reported by four respondents, including Fábio: "I try to think of other things, I try to find a way out at the end of the tunnel, I try to ignore sometimes, but I can 't, I try to dodge". Fabio cited the three techniques most used by respondents - think of something else, ignore, and shirk (avoid direct confrontation). However, this type of strategy had little effect on understanding and improving the relationship with voices.

The passive coping strategies (lying in bed, hearing the voices, and allowing to be overwhelmed by emotions and feelings, without reacting) were used by three participants. However, they reported the most acute suffering compared to those who performed active strategies. In addition, the experiments were longer and more frequent during the day, and although they had tried effective coping strategies at other times, they were often unable to use them. 
Thus, we can infer that movement is a basic principle for dealing with voices. The data found are largely in line with the literature (Farhall et al., 2007; Baker, 2009; Romme et al., 2009) and corroborate Larøi (2012), who argued that passive coping strategies increase the risk of worsening clinical condition; besides that, the voice hearer should use the method that is most effective for him, since the use of misfit strategies may lead to greater suffering (De LeedeSmith \& Barkus, 2013).

\section{Family Support}

This category gathers data that indicate the importance of family and/or social support in the recovery process. Larissa's speech illustrates this statement:

I have my daughter, who helps me a lot, who is my partner, and that's why I'm still alive, our relationship is very good, very beautiful, she has a very good dialogue with me we, we are very sincere with each other, but then the only thing that really bothers $m e$ is the voices.

Larissa and five other interviewees received good family support at the time of the research (with listening and openness to dialogue) and reported that this support had been important for the recovery process, regarding non-hospitalizations. Nonetheless, in Larissa's report, there is a point that draws attention: despite the support of her daughter and parents (which she quoted elsewhere in the interview), the voices continued to bother her. This data problematizes some findings in the literature such as Norman et al. (2005), who claim that there is a correlation between family support and reduction in hallucinatory experiences, which was common to respondents, as they continued to have many experiences with voices despite family support.

However, it was possible to observe the opposite scenario: the lack of support or the existence of a conflicting relationship with family members points to the aggravation not only of hallucinatory experiences, but also of suffering, as reported by Reinaldo:

I prefer to hold it inside myself, because I have told my mother many times, she says that I'm crazy, which is something in my head, ends in discussion, confusion. If talking to my father, he does not pay attention to me, not to my sister, and she does not believe what I feel she wants to preach and then emerges discussion so I stopped talking.

The lack of listening and disqualification of Reinaldo's relatives ended up generating conflicts and crises, and it was a common fact among the interviewees: six of them reported that in the first experiences with the voices, the family members thought they had gone "crazy" and three stated that they were considered "sick". Only one had his difficulty accepted (he was taken to a Spiritist Center to develop mediumship). Eight respondents had at least one mental hospital stay and because of the violence suffered in these places, their relatives prefer not to make use of this resource. Fábio described the way family members viewed his situation:

They call me sick, crazy, complain about having to buy medicine, they charge things I can't give yet, but the disease doesn't allow me to work, they don't understand much, that a person who needs help, not hostility. When I get into crisis, they help with the medicine, hospital. It's as if they don 't believe I'm sick, as if I've chosen to be sick.

In this excerpt, it is evident a moral judgment conferred on the voices of Fábio. What stands out most in his case is that other family members also hear voices, but because they can perform their activities without such limitations (such as working, for example), they think he also can, and put pressure and demands on him. Consequently, this posture interferes with the possibility of improving both the relationship with the voices and their health status.

Another element in the attitudes of relatives of Reinaldo, Fábio and five other interviewees is the attribution of religious meaning to the voices. This issue can also contribute to the intensification of the manifestations, since depending on the way such attribution is made and the voice hearer's belief (which may not be the same as the other family members), negative valence feelings and emotions can be generated, which will act as triggers for the voices. This situation happened to Micaela. Her mother is part of a neo-Pentecostal religion and used to hear from the pastor that hallucinations were a thing of the devil and that people had to be exorcised to get it out of his/her body.

Micaela's mother's attitude has already led the interviewee to have seizures, since she feels guilty, becomes extremely angry and usually seeks the path of isolation. Because of these and other issues with family members (such as the prejudice disguised as "jokes" or the threat of hospitalization in the mental hospital) five respondents said they chose not to share their voice-hearer condition - an issue that may also lead to the intensification of hallucinations and the crisis.

Although family support is not a sufficient condition for the reduction of voice hearing - and therefore, other factors (such as the "origin" of voices) should be explored in the analysis and management of the phenomenon - we emphasize that when this does not happen increase the chance that the hearer will start a psychiatric career. And in turn, this issue has implications for the hearer of voices such as medicalization, social stigma, increased suffering and other limitations of various orders - as occurred with Marcela, moments after her first voice hearing experience: 
I got home, called my family and said "guys, I'm paranormal!". My mother said, "Marcela, let's go" and took me to the psychiatrist. And the psychiatrist, who is evangelical, said "this is schizophrenia", and prescribed Lithium and other drugs, and then I was getting worse.

Marcela's report and several others that have been presented throughout this study underscore the fact that the family can establish itself as an essential support network, as in many cases it is the first (and perhaps the only) environment that a person can look for help. Thus, family members or caregivers are recommended to take a welcoming posture and to assist the voice hearer in understanding their experiences through listening and open dialogue.

\section{FINAL CONSIDERATIONS}

The results of this study showed dimensions of life that may be governing the experiences with the voices, structured in contexts of suffering that could not be named and/or shared. Understanding the phenomenon merely as a symptom of mental illness is therefore not the most appropriate way, as it carries a multiplicity of meanings that can guide the process of coping and recovery (Longden et al., 2012). Thus, the first point to be stressed is the need to listen to what the person or the voices the person hears have to say.

According to the reports, contexts of violence indelibly marked the lives of respondents, bringing several losses. When it comes to women who hear voices, it is possible that they have suffered or still suffer violence - an issue that is common to be found in the reports of women seeking mental health services (Pedrosa \& Zanello, 2016). It is noteworthy that gender issues can condition or determine the disease - as observed in some reports - and that not taking them into consideration in the follow-up and treatment of these cases can aggravate the situation (Zanello \& Silva, 2012). The issue of violence, therefore, should be explored in depth in the care of Brazilian voice hearers, considering the involvement of elements specific to our culture that differ from data from researchers linked to HVM/Intervoice - mostly obtained in less violent countries and with higher educational level.

Although religiosity and spirituality appeared as a cross-sectional theme that tied together the experiences in three out of the four categories "origin" of voices, coping strategies and family support the same was not observed in the analyzed HVM/Intervoice literature - which did not present them so often. As with the issue of violence, it is necessary to think about cultural specificities related to these two dimensions in Brazil, considering that we are marked by a strong religious syncretism, with deep historical roots. In other words, to understand voice hearing experiences in our country, it is necessary to consider that interventions and contacts with spiritual beings are central, frequent and tangible elements in the lives of millions of people (Bizerril, 2007).

Further, it is considered essential to listen and dialogue about these experiences, as well as develop activities that reduce the emotional burden for voice hearers. It is also considered important that professionals can provide support for building networks (friends, family, and health), as these are indispensable to the recovery process. Another alternative considered crucial to approach such an experience would be the creation of groups of voice hearers, as they provide a context that facilitates their understanding and consequently reduces some of their impacts (Romme, 2009a).

This study has some limitations, such as a small sample and the use of a semi-structured script in interviews guided by a line of thought. Thus, there is a risk of generalizing the results found, although they are aligned with the specialized literature. It is also important to highlight that some studies point to a physiological component in relation to the voice hearing phenomenon and that there is a scientific field of research for such studies. Therefore, it is necessary to analyze each case and to focus the therapeutic plan on the protagonist, the voice hearer, based on what suits best.

Despite the limitations, this study offers some important reflections for the mental health field with data that indicate possibilities of understanding and care regarding this phenomenon, emphasizing to family members, professionals and voice hearers the importance of treating the issue beyond biomedical reductionism. It also aims to contribute and encourage more research related to the theme, exploring issues related to gender, race, sexual orientation, religious beliefs and non-clinical populations, among others, in view of the possibility of providing a higher quality of life and support for voice hearers and their caregivers. 


\section{REFERENCES}

Almeida, A.M., \& Lotufo Neto, F. (2003). Diretrizes metodológicas para investigar estados alterados de consciência e experiências anômalas. Revista de Psiquiatria Clínica, 30(1), 21-28. https:// doi.org/10.1590/S0101-60832003000100003

Almeida, A. M. (2004). Fenomenologia das experiências mediúnicas, perfil e psicopatologia de médiuns espiritas (Tese de doutorado). Universidade de São Paulo, São Paulo, SP, Brasil.

Almeida, A.M., Lotufo Neto, F., \& Koenig, H.G. (2006). Religiousness and mental health: A review. Revista Brasileira de Psiquiatria, 28(3), 242-50. https://doi.org/10.1590/S151644462006005000006

Almeida, A.M., \& Cardeña, E. (2011). Diagnóstico diferencial entre experiências espirituais e psicóticas não patológicas e transtornos mentais: uma contribuição de estudos latino-americanos para o CID-11. Revista Brasileira de Psiquiatria, 33(1), S21-S28. https://doi.org/10.1590/S1516-44462011000500004

Alminhana, L.O., \& Menezes, A. Jr. (2016). Experiências Religiosas/Espirituais: Dissociação saudável ou patológica? Horizonte, 14(41), 122-143. https://doi.org/10.5752/P.2175$5841.2016 \mathrm{v} 14 \mathrm{n} 41 \mathrm{p} 122$

Baccari, I. O. P., Onocko Campos, R. T., \& Stefanello, S. (2015). Recovery: Revisão sistemática de um conceito. Ciência \& Saúde Coletiva, 20(1), 125-136. https://doi.org/10.1590/141381232014201.04662013

Badcock, J. C., \& Chhabra, S. (2013). Voices to reckon with: Perceptions of voice identity in clinical and non-clinical voice hearers. Frontiers in Human Neuroscience, 7, 1-9. https:// dx.doi.org/10.3389\%2Ffnhum.2013.00114

Baker, P. (2009). The voice inside: A practical guide for and about people who hear voices. P\&P Press.

Bardin, L. (2016). Análise de conteúdo. Edições 70.

Barnes, J., Koch, L., Wilford, C., \& Boubert, L. (2011). An investigation into personality, stress and sleep with reports of hallucinations in a normal population. Psychology, 2(4), 371375. http://dx.doi.org/10.4236/psych.2011.24058

Baumeister, D., Sedgwick, O., Howes, O., \& Peters, E. (2016). Auditory verbal hallucinations and continuum models of psychosis: A systematic review of the healthy voice-hearer literature. Clinical Psychology Review, 51, 125-141. https:// doi.org/10.1016/j.cpr.2016.10.010

Beavan, V., \& Read, J. (2010). Hearing voices and listening to what they say: The importance of voice content in understanding and working with distressing voices. The Journal of Nervous and Mental Disease, 198, 201-205. https://doi.org/10.1097/ NMD.0b013e3181d14612

Bizerril, J. (2007). Dilemas classificatórios: Fronteiras entre a experiência religiosa e a psicopatologia. In M. H. Freitas \& O. P. Pereira (Eds.), Vozes do silenciado: Estudos nas fronteiras da filosofia, antropologia e psicologia (pp. 129-152). Universa.

Campos, I. O., \& Zanello, V. (2016). Saúde mental e gênero: O sofrimento psíquico e a invisibilidade das violências. Vivência: Revista de Antropologia, 1(48), 105-117. https://periodicos. ufrn.br/vivencia/article/view/11505

Corstens, D., Longden, E., McCarthy-Jones, S., Waddingham, R., \& Thomas, N. (2014). Emerging perspectives from the hearing voices movement: Implications for research and practice. Schizophrenia Bulletin, 40, S285-S294. https://doi. org/10.1093/schbul/sbu007

Costa, I. I. (2013). Intervenção precoce e crise psíquica grave: Fenomenologia do sofrimento psíquico. Juruá.

Costa, I. I., \& Braga, F. W. (2013). Clínica sensível à cultura popular na atenção ao sofrimento psíquico grave. Fractal, 25(3), $547-$ 562. https://doi.org/10.1590/S1984-02922013000300009
Daalman, K., Boks, M. P. M., Diederen, K. M. G., Weijer, A. D., Blom, J. D., Kahn, R. S., \& Sommer, I. E. C. (2011). The same or different? A phenomenological comparison of auditory verbal hallucinations in healthy and psychotic individuals. Journal of Clinical Psychiatry, 72(3), 320-325. https://doi. org/10.4088/JCP.09m05797yel

De Leede-Smith, S., \& Barkus, E. (2013). A comprehensive review of auditory verbal hallucinations: lifetime prevalence, correlates and mechanisms in healthy and clinical individuals. Frontiers in Human Neuroscience, 7, 1-25. https://doi. org/10.3389/fnhum.2013.00367

Escher, S. (2009a). Making sense of voices: The relationship between the voices and the life history. In M. Romme, S. Escher, J. Dillon, D. Corstens, \& M. Morris (Eds.), Living with voices: 50 stories of recovery (pp. 54-62). PCCS Books.

Escher, S. (2009b). Accepting voices and finding a way out. In M. Romme, S. Escher, J. Dillon, D. Corstens, \& M. Morris (Eds.), Living with voices: 50 stories of recovery (pp. 48-53). PCCS Books.

Escher, S., Hage, P., \& Romme, M. (2011). Voice hearing: A questionnaire. http://www.hearingvoices.org.nz

Farhall, J., Greenwood, K.M., \& Jackson, H.J. (2007). Coping with hallucinated voices in schizophrenia: A review of self-initiated strategies and therapeutic interventions. Clinical Psychology Review, 27, 476-493. https://doi.org/10.1016/j.cpr.2006.12.002

Freeman, D., \& Garety, P.A. (2003). Connecting neurosis and psychosis: The direct influence of emotion on delusions and hallucinations. Behaviour Research and Therapy, 41, 923-947. https://doi.org/10.1016/s0005-7967(02)00104-3

Godoy, D. B. D. O. A. (2012). Modelagem topológica da possessão: Sujeito e alteridade na umbanda (Tese de doutorado). Universidade de São Paulo, São Paulo, SP, Brasil.

Hardy, S. A., \& Carlo, G. (2005). Religiosity and prosocial behaviours in adolescence: The mediating role of prosocial values. Journal of Moral Education, 34(2), 231-249. https:// doi.org/10.1080/03057240500127210

Harkavy-Friedman, J. M., Kimhy, D., Nelson, E. A., Venarde, D. F., Malaspina, D., \& Mann, J. J. (2003). Suicide attempts in schizophrenia: The role of command auditory hallucinations for suicide. Journal of Clinical Psychiatry, 64, 871-874.

Hill, K., \& Linden, D. E. J. (2013). Hallucinatory experiences in non-clinical populations. In R. Jardri, A., Cachia, P., Thomas, $\&$ D. Pins (Eds.), The Neuroscience of Hallucinations (pp. 21-41). Springer.

Honig, A., Romme, M., Ensink, B. J., Escher, S. D., Pennings, M. H., \& deVries, M. W. (1998). Auditory hallucinations: A comparison between patients and nonpatients. The Journal of Nervous and Mental Disease, 186(10), 646-651. https://doi. org/10.1097/00005053-199810000-00009

Kalhovde, A. M., Elstad, I., \& Talseth, A. G. (2013). Understanding the experiences of hearing voices and sounds others do not hear. Qualitative Health Research, 23(11), 1470-1480. https://doi. org/10.1177/1049732313507502

Koenig, H. G., King, D. E., \& Carson, V. B. (2012). Handbook of religion and health. Oxford University Press.

Kråkvik, B., Larøi, F., Kalhovde, A. M., Hugdahl, K., Kompus, K., Salvesen, Ø., \& Vedul-Kjelsås, E. (2015). Prevalence of auditory verbal hallucinations in a general population: A group comparison study. Scandinavian Journal of Psychology, 56, 508-515. https://dx.doi.org/10.1111\%2Fsjop.12236

Larøi, F. (2012). How do auditory verbal hallucinations in patients differ from those in non-patients? Frontiers in Human Neuroscience, 6, 1-9. https://dx.doi. org/10.3389\%2Ffnhum.2012.00025 
Longden, E., Corstens, D., Escher, S., \& Romme, M. (2012). Voice hearing in a biographical context: A model for formulating the relationship between voices and life history. Psychosis, 4, 224-234. https://doi.org/10.1080/17522439.2011.596566

Longden, E., Madill, A., \& Waterman, M.G. (2012). Dissociation, trauma, and the role of lived experience: toward a new conceptualization of voice hearing. Psychological Bulletin, 138(1), 28-76. https://doi.org/10.1037/a0025995

Longden, E., Corstens, D., \& Dillon, J. (2013). Recovery, discovery and revolution: The work of Intervoice and the hearing voices movement. In S. Coles, S. Keenan, \& B. Diamond (Eds.), Madness contested: power and practice (pp. 161-180). PCCS Books.

McCarthy-Jones, S., Thomas, N., Strauss, C., Dogdson, G., Jones, N., Woods, A., Brewin, C. R., Hayward, M., Stephane, M., Barton, J., Kingdon, D., \& Sommer, I. E. (2014). Better than mermaids and stray dogs? Subtyping auditory verbal hallucinations and its implications for research and practice. Schizophrenia Bulletin, 40(4), S275-S284. https://doi. org/10.1093/schbul/sbu018

Menezes, A. Jr., \& Almeida, A. M. (2009). Differential diagnosis between spiritual experiences and mental disorders of religious content. Revista de Psiquiatria Clínica, 36(2), 75-82. https:// doi.org/10.1590/S0101-60832009000200006

Norman, R. M. G., Malla, A. K., Manchanda, R., Harricharan, R., Takhar, J., \& Northcott, S. (2005). Social support and three-year symptom and admission outcomes for first episode psychosis. Schizophrenia Research, 80, 227-234. https://doi. org/10.1016/j.schres.2005.05.006

O'sullivan, K. (1994). Dimensiona of coping with auditory hallucinations. Journal of Mental Health, 3, 351-361. https:// doi.org/10.3109/09638239408997946

Pedrosa, M., \& Zanello, V. (2016). (In)visibilidade da violência contra as mulheres no serviço de saúde mental. Psicologia: Teoria e Pesquisa, 32(n. Esp), 1-8. https://doi.org/10.1590/01023772e32ne214

Read, J., Agar, L., Argyle, N., \& Aderhold, V. (2003). Sexual and physical abuse during childhood and adulthood as predictors of hallucinations, delusions and thought disorder. Psychology and Psychotherapy: Theory, Research and Practice, 76, 1-22. https://doi.org/10.1348/14760830260569210

Romme, M. (2009a). Hearing voices groups. In M. Romme, S. Escher, J. Dillon, D. Corstens, \& M. Morris (Eds.), Living with voices: 50 stories of recovery (pp. 73-85). PCCS Books.

Romme, M. (2009b). What causes hearing voices? In M. Romme, S. Escher, J. Dillon, D. Corstens, \& M. Morris (Eds.), Living with voices: 50 stories of recovery (pp. 39-47). PCCS Books.

Romme, M, Escher, S., Dillon, J., Corstens, D., \& Morris, M. (2009). Living with voices: 50 stories of recovery. PCCS Books.

Shevlin, M., Dorahy, M., \& Adamson, G. (2007). Childhood traumas and hallucinations: An analysis of the National Comorbidity Survey. Journal of Psychiatric Research, 41(3), 222-228. https://doi.org/10.1016/j.jpsychires.2006.03.004

Taylor, P. J., Gooding, P. A., Wood, A. M., Johnson, J., Pratt, D., \& Tarrier, N. (2010). Defeat and entrapment in schizophrenia: The relationship with suicidal ideation and positive psychotic symptoms. Psychiatry Research, 178, 244-248. https://doi. org/10.1016/j.psychres.2009.10.015

Telles-Correia, D., Moreira, A. L., \& Gonçalves, J. S. (2015). Hallucinations and related concepts - Their conceptual background. Frontiers in Psychology, 6, 1-9. https://dx.doi. org/10.3389\%2Ffpsyg.2015.00991

World Health Organization. (2013). Responding to intimate partner violence and sexual violence against women: WHO clinical and policy guidelines. http://apps.who.int

World Health Organization. (2014). Health for the world's adolescents: A second chance in the second decade. https:// www.who.int

World Health Organization. (2014). Relatório mundial sobre a prevenção da violência (Núcleo de Estudos da Violência da Universidade de São Paulo, Trad.). http://nevusp.org

Zanello, V., \& Silva, R. M. C. (2012). Saúde mental, gênero e violência estrutural. Revista Bioética, 20(2), 267-279. http:// revistabioetica.cfm.org.br/index.php/revista_bioetica/article/ view/745 